\title{
Możliwości wykorzystania rówieśniczego tutoringu w edukacji dzieci z niepełnosprawnością intelektualną
}

\begin{abstract}
Twardowski Andrzej, Possibilities of using peer tutoring in the education of children with intellectual disability [Możliwości wykorzystania rówieśniczego tutoringu w edukacji dzieci $\mathrm{z}$ niepełnosprawnością intelektualną]. Interdyscyplinarne Konteksty Pedagogiki Specjalnej, nr 5, Poznań 2014. Pp. 17-39. Adam Mickiewicz University Press. ISBN 978-83-232-2866-0. ISSN 2300-391X.
\end{abstract}

Inclusion of able peers into the process of aiding the development of disabled children is beneficial for both groups. Able children have the opportunity to get to know disabled peers better, to understand them and to develop an accepting attitude toward them. Disabled children have the opportunity to learn that their able peers pay attention to them and are willing to play and talk to them. They also have a chance to experience that they can successfully influence other people. What is more, their autonomy increases since they have to relay more on themselves in interaction with peers.

In the article the author analyzes the following issues: 1) theoretical basis of peer tutoring; 2) types of teaching interaction between children; 3) preparing the non-disabled peers for the role of tutors; 4) effectiveness of peer tutoring in teaching children with intellectual disabilities; 5) role of the teacher as an organizer of peer tutoring; 6) questions that require verification by future research.

KEY WORDS: peer tutoring, intellectual disability, education, psychological development. 
Wstęp

Interakcje z rówieśnikami sprzyjają rozwojowi poznawczemu, społeczno-moralnemu, emocjonalnemu i językowemu dziecka. Zdaniem Davida Fontany, czasami dziecko może uzyskać bardziej skuteczną pomoc od rówieśnika niż od osoby dorosłej ${ }^{1}$. Dzieci potrafią np. bardzo precyzyjnie określić trudności swoich kolegów. Aby porozumieć się z nimi, starają się mówić w sposób jak najbardziej przystępny dla partnera. To $\mathrm{w}$ relacjach $\mathrm{z}$ rówieśnikami, a nie $\mathrm{z}$ dorosłymi dziecko opanowuje takie umiejętności społeczne, jak: współpraca z innymi, udzielanie pomocy, dzielenie się, obrona własnych interesów, negocjowanie, osiąganie kompromisów, podporządkowywanie się kierownictwu innych i odgrywanie roli przywódcy. Interakcje $\mathrm{z}$ rówieśnikami wspierają rozwój poznawczy. Stwierdzono, że już sama obecność kolegów wpływa mobilizująco na aktywność umysłową dziecka. Na przykład dzieci w wieku przedszkolnym $\mathrm{w}$ obecności rówieśników rozwiązywały zadania szybciej i lepiej niż w samotności². Kontakty z rówieśnikami pobudzają również rozwój emocjonalny dziecka. Sprzyjają kształtowaniu się zdolności do empatii oraz samokontroli emocjonalnej, umiejętności wyrażania emocji w sposób społecznie akceptowany i rozpoznawania emocji partnerów.

Do końca lat 70. ubiegłego wieku dziecko było traktowane jako bierny odbiorca edukacyjnych oddziaływań dorosłych, swoiste „puste naczynie”, które stopniowo, dzięki wpływom dorosłych, „napełnia się" wiedzą i umiejętnościami. Zgodnie z powszechnym przekonaniem, oddziaływania edukacyjne miały przebiegać $\mathrm{w}$ jednym kierunku: od dorosłego do dziecka. Nie brano pod uwagę tego, iż dzieci mogą uczyć się od siebie nawzajem. Dopiero Hugh Foot, Michelle Morgan i Rosalyn Shute szeroko udokumentowali,

${ }^{1}$ D. Fontana, Where do we go from here? A personal view by an educationalist, [w:] Children helping children, red. H.C. Foot, M.J. Morgan, R.H. Shute, John Willey \& Sons, New York 1990, s. 376.

2 C.R. Cooper, Development of collaborative problem-solving among preschool children, „Developmental Psychology”, 1980, nr 5, s. 433-440. 
że dzieci potrafią odgrywać role nauczycieli i pomocników - jeżeli stworzy się im odpowiednie warunki oraz uczyni współodpowiedzialnymi za przebieg procesu uczenia ${ }^{3}$.

Jak wskazują dotychczasowe badania i doświadczenia praktyczne, nauczanie prowadzone przez rówieśników przyczynia się do wzrostu osiągnięć szkolnych uczniów oraz tworzy bardziej przyjazną atmosferę w klasie. Uczniowie mają możliwość dzielenia się swoimi pomysłami i wymiany posiadanych wiadomości. Skutkuje to ich większym zaangażowaniem się $\mathrm{w}$ wykonywane zadania, podwyższa kreatywność, a przede wszystkim zwiększa liczbę osób, od których mogą pozyskiwać wiadomości oraz umiejętności.

\section{Teoretyczne podstawy rówieśniczego tutoringu}

Koncepcja rówieśniczego tutoringu znajduje uzasadnienie w dwóch fundamentalnych dla psychologii rozwojowej koncepcjach teoretycznych: Jeana Piageta i Lwa Wygotskiego. Pomimo że Piaget i Wygotski prezentują odmienne punkty widzenia odnośnie roli rówieśników w procesie rozwoju, to $\mathrm{w}$ niektórych kwestiach ich podejścia wykazują uderzające podobieństwa ${ }^{4}$. Obaj akcentują współzależność organizmu i środowiska oraz podzielają przekonanie, że dzieci aktywnie uczestniczą we własnym rozwoju.

Jak wskazywał J. Piaget, kontakty rówieśnicze w okresie przedoperacyjnym stymulują przezwyciężanie egocentryzmu, ponieważ wymagają tego, aby dzieci porównywały swoje perspektywy poznawcze. $W$ relacjach dorosły - dziecko dominuje natomiast punkt widzenia dorosłego, co zniechęca dziecko do wyjaśniania swojej perspektywy poznawczej poprzez porównanie jej z perspektywą partnera. Dziecko może np. traktować pytania dorosłego jako próbę sprawdzenia, czy zrozumiało jego wypowiedź, a nie jako zaprosze-

${ }^{3}$ Children helping children, ed. cit.

${ }^{4}$ J. Tudge, B. Rogoff, Wptyw rówieśników na rozwój poznawczy - podejście Piageta $i$ Wygotskiego, [w:] Dziecko wśród rówieśników i dorostych, red. A. Brzezińska, G. Lutomski, B. Smykowski, Wydawnictwo Zysk i S-ka, Poznań 1995, s. 181. 
nie do wspólnego rozwiązania problemu. Inaczej jest w relacjach z rówieśnikami, które charakteryzują się równowagą zdolności poznawczych i władzy. Kiedy partner ma odmienne zdanie, dziecko dąży do wyjaśnienia swojego punktu widzenia poprzez skonfrontowanie go z jego stanowiskiem.

Myśli J. Piageta zostały rozwinięte przez Anne-Nelly Perret-Clermont i jej współpracowników. Ich zdaniem, mechanizm powodujący zmianę stanowi konflikt społeczno-poznawczy. Konflikt pojawia się $\mathrm{w}$ trakcie wspólnego rozwiązywania zadań, kiedy dziecko natrafia na odmienny, choć niekoniecznie właściwy punkt widzenia prezentowany przez partnera. W takiej sytuacji konieczna jest poznawcza rekonstrukcja, ponieważ dziecko musi powiązać ideę zaproponowaną przez partnera $z$ własnym pomysłem na rozwiązanie zadania. Innymi słowy, pojawienie się konfliktu między perspektywą własną a perspektywą partnera zmusza dziecko do przekształcenia dotychczasowej reprezentacji. W rezultacie uzyskuje ono nową wiedzę, która nie jest prostą sumą informacji posiadanych przez nie i partnera ${ }^{5}$. A zatem interakcja społeczna staje się źródłem postępu w rozwoju poznawczym dzięki temu, że prowadzi do konfliktu społeczno-poznawczego. „Oczywiście konflikt społeczno-poznawczy sam z siebie nie tworzy nowych form operacji umysłowych, natomiast doprowadza do utraty równowagi, co z kolei wyzwala aktywność poznawczą. Konflikt społeczno-poznawczy działa jak katalizator w reakcji chemicznej: choć nie jest obecny w końcowym produkcie, to jest niezbędny, aby reakcja mogła nastąpić"6. Kontakty z rówieśnikami wywołują więc konflikty społeczno-poznawcze i zmuszają do ich rozwiązywania. Tym samym skłaniają partnerów do intelektualnej współpracy oraz przyczyniają się do przezwyciężenia przez nich egocentryzmu poznawczego.

${ }^{5} \mathrm{~W}$. Doise, The development of individual competencies through social interaction, [w:] Children helping children, ed. cit., s. 49-54.

${ }^{6}$ A.-N. Perret-Clermont, Social interaction and cognitive development in children, Academic Press, London 1980, s. 178. 
Odmienne stanowisko $\mathrm{w}$ kwestii roli relacji $\mathrm{z}$ rówieśnikami w procesie rozwoju dziecka zajmował L. Wygotski. Analizował on sposoby, za których pomocą bardziej dojrzali uczestnicy kultury przekazują mniej dojrzałym jednostkom kulturowo akceptowane praktyki, działania i narzędzia, przede wszystkim język. Zdaniem Wygotskiego, rozwój może dokonywać się w relacji z kimś, kto wie więcej o tych narzędziach, czyli z dorosłym lub bardziej kompetentnym rówieśnikiem. Wszystkie umiejętności i wiedza najpierw są doświadczane w procesie interakcji społecznej, a dopiero później zostają zinternalizowane i podlegają dekonstualizacji. „Każda z wyższych funkcji psychicznych była dlatego zewnętrzna, że była funkcją społeczną, zanim stała się wewnętrzna; zanim stała się funkcją ściśle psychiczną, była poprzednio stosunkiem społecznym dwojga ludzi"7. Bez pośrednictwa, współpracy i pomocy innych osób istota ludzka nie byłaby w stanie rozwinąć swoich procesów poznawczych oraz wytworzyć poznawczej reprezentacji otaczającej ją rzeczywistości. Dla Wygotskiego idealni partnerzy nie są sobie równi, przy czym nierówność dotyczy rozumienia, a nie władzy. „Z tego powodu zarówno dorośli, jak i rówieśnicy mogą przyczynić się do rozwoju poznawczego dziecka w toku interakcji. Aby jednak rozwój ten mógł zachodzić podczas interakcji rówieśniczej, konieczny jest wyższy stopień przygotowania któregoś z partnerów"8.

\section{Rodzaje nauczających interakcji z rówieśnikami}

Można wyróżnić dwa rodzaje rówieśniczych interakcji o charakterze nauczającym: uczenie przez rówieśnika (peer tutoring) oraz uczenie się z rówieśnikiem (peer collaboration).

Pojęcie „uczenie przez rówieśnika” opisuje taką sytuację, w której jedno dziecko (tutor) pomaga drugiemu (uczniowi) opanować określone wiadomości i umiejętności poprzez dostarczanie mu

7 L.S. Wygotski, Wybrane prace psychologiczne, PWN, Warszawa 1971, s. 132-133.

8 J. Tudge, B. Rogoff, op. cit., s. 191. 
wskazówek oraz porad lub bezpośrednie kierowanie jego czynnościami. Zazwyczaj tutorzy są w tym samym wieku metrykalnym co uczniowie, a tylko czasami bywają nieco starsi od nich. Pomimo tego samego lub zbliżonego wieku, między dziećmi występuje natomiast różnica poziomu kompetencji. Tutor znajduje się na wyższym poziomie wiedzy i umiejętności niż uczeń. Obaj mają świadomość tego, kto jest ekspertem, czyli tym, kto uczy (tutor), a kto nowicjuszem, czyli tym, kto jest uczony (uczeń). Pomiędzy nimi zachodzi relacja o charakterze asymetrycznym. Ekspert dostarcza informacji i instrukcji oraz kieruje wysiłkami ucznia zmierzającymi do rozwiązania określonego zadania. Teoretycznego uzasadnienia dla tego rodzaju nauczającej interakcji dostarcza koncepcja L. Wygotskiego oraz prace kontynuatorów jego myśli, takich jak Jerome Bruner, David Wood oraz James Wertsch.

Termin „uczenie się z rówieśnikiem” dotyczy sytuacji, w której dwoje dzieci o podobnym poziomie zdolności próbuje rozwiązać określone zadanie. $\mathrm{W}$ tym celu wymieniają się one informacjami. Wiedza posiadana przez każde $\mathrm{z}$ nich jest niepełna i dlatego żadne nie potrafi rozwiązać zadania samodzielnie. Mogą je natomiast zrealizować we współpracy, dzięki wymianie posiadanych informacji oraz pomaganiu sobie nawzajem $w$ zdobywaniu nowych. Takie uczenie się poprzez wspólne odkrywanie dokonuje się $\mathrm{w}$ ramach symetrycznej relacji, w atmosferze wzajemnej sympatii i przy równym zaangażowaniu obojga partnerów. Teoretycznego uzasadnienia dla tego rodzaju nauczającej interakcji między dziećmi dostarcza teoria rozwoju poznawczego J. Piageta, a szczególnie prace grupy A.-N. Perret-Clermont.

Uczenie się we współpracy z rówieśnikami może odbywać się również na tych lekcjach, na których jest wykorzystywana metoda pracy w grupach ${ }^{9}$. Uczniowie wykonują zadania w małych, czterolub pięcioosobowych zespołach. Nagradza się ich za rozwiązania,

\footnotetext{
${ }_{9}$ W. Damond, E. Phelps, Strategies uses of peer learning in children's education, [w:] Peer relationships in child development, red. T.J. Berndt, G.W. Ladd, John Willey \& Sons, New York 1989, s. 135-157.
} 
do których dochodzą dzięki wspólnym wysiłkom. Zadania są tak pomyślane, aby uczniowie podczas poszukiwania rozwiązania musieli ze sobą współpracować - wymieniać się informacjami, wyjaśniać sobie pewne kwestie, dyskutować, zadawać pytania, wspólnie zastanawiać się nad różnymi pomysłami. Dzięki staraniom nauczyciela nauczające interakcje mogą pojawiać się również $\mathrm{w}$ toku tradycyjnej lekcji. W tym celu powinien on zachęcać dzieci, by w sytuacji pojawienia się jakiejś trudności zwracały się o pomoc do innego dziecka. Należy dodać, że do wspólnego uczenia się dochodzi w licznych sytuacjach poza klasą szkolną, gdy dziecko przebywa $\mathrm{w}$ nieformalnej grupie rówieśniczej lub domu rodzinnym. Wówczas w roli tutorów występują rówieśnicy z sąsiedztwa oraz rodzeństwo.

\section{Przygotowanie pełnosprawnych rówieśników do roli tutorów}

Aby pełnosprawni rówieśnicy mogli występować $\mathrm{w}$ roli tutorów, muszą opanować w trakcie specjalnie zorganizowanego szkolenia określone umiejętności. Szkolenie to może mieć charakter indywidualny lub zespołowy i powinno składać się z następujących etapów: 1) przedstawienie szczegółowego opisu danej umiejętności; 2) zademonstrowanie umiejętności przez nauczyciela; 3) ćwiczenie umiejętności $\mathrm{w}$ relacji z nauczycielem za pomocą metody grania ról; 4) posługiwanie się nabytą umiejętnością $w$ relacjach $z$ niepełnosprawnymi rówieśnikami $\mathrm{w}$ sytuacjach grania ról; 5) używanie nabytej umiejętności $\mathrm{w}$ relacjach $\mathrm{z}$ pełnosprawnymi rówieśnikami w naturalnych sytuacjach ${ }^{10}$. Ten ostatni etap jest szczególnie ważny, ponieważ podczas przenoszenia nabytych umiejętności z sytuacji treningowych na realne mogą pojawić się niespodziewane trudności. Niektórzy autorzy uważają, że na początku szkolenia sprawne

${ }^{10}$ E. Murphy, I.M. Grey, R. Honan, Co-operative learning for students with difficulties in learning: a description of model and guidelines for implementation, "British Journal of Special Education", 2005, nr 3, s. 161-162. 
dzieci powinny zostać zaznajomione z celami rówieśniczego tutoringu, a na zakończenie każdej sesji muszą mieć możliwość wyrażenia własnych opinii na temat uczonej umiejętności. Autorzy ci podkreślają również konieczność monitorowania nauczających oddziaływań tutorów po zakończeniu szkolenia i systematycznego przekazywania im informacji zwrotnych ${ }^{11}$.

Pierwszą udaną próbę włączenia dzieci pełnosprawnych w proces edukacji niepełnosprawnych rówieśników podjęli Phillip Strain i jego współpracownicy ${ }^{12}$. Za pomocą procedury modelowania nauczyli oni czteroletnie dzieci o wysokim poziomie inteligencji (powyżej 130 punktów) oraz rozwoju społecznego różnych sposobów zapraszania niepełnosprawnych kolegów do wspólnej zabawy. Sesje treningowe miały formę 20- lub 30-minutowych zajęć, prowadzonych z każdym dzieckiem indywidualnie. Najpierw terapeuta prosił dziecko, aby podało wszystkie wypowiedzi, za których pomocą starałoby się zainicjować zabawę z niepełnosprawnym intelektualnie rówieśnikiem. W ten sposób ustalano, jakim repertuarem wypowiedzi inicjujących interakcje dysponuje dziecko. Następnie uczono je nowych. Terapeuta podawał dziecku przykłady inicjujących wypowiedzi: „Pobawimy się?”, „Chciałbyś poukładać ze mną klocki?”, „Pobawimy się samochodzikami?". Następnie prosił dziecko, aby włączyło go do wspólnej zabawy z użyciem jak największej liczby wypowiedzi tego typu. Na co drugą z nich reagował pozytywnie: „Bardzo dobrze, to może zachęcić twojego kolegę do zabawy”. Pozostałe wypowiedzi ignorował - milczał przez 10 sekund, a następnie mówił: „Czasami twój kolega nie będzie chciał się bawić. Nie martw się, spróbuj jeszcze raz”. W dalszej kolejności dzieci uczyły się nawiązywania interakcji za pomocą zabawek. Terapeuta demonstrował próbki takich zachowań - np. podchodził do dziecka z piłką i mówił: „Pobawimy się piłką?”, "Chcesz pograć

11 E.W. Carter, L.S. Cushing, C.H. Kennedy, Peer support strategies: improving all student's social lives and learning, Paul H. Brookes, Baltimore 2009, s. 48-50.

12 Ph.S. Strain, R.E. Shores, M.A. Timm, Effects of peer social initiations on the behavior of withdrawn preschool children, "Journal of Applied Behavior Analysis", 1977 , nr 2, s. 289-298. 
w piłkę?", „Rzucisz piłkę do mnie?”. Następnie prosił dziecko, aby próbowało włączyć go do wspólnej zabawy w taki lub podobny sposób. Tak jak poprzednio, po niektórych próbach stosował pochwały, a po innych nie reagował i zachęcał dziecko do użycia kolejnych wypowiedzi inicjujących.

Po zakończeniu opisanego wyżej szkolenia dzieci posługiwały się nabytymi umiejętnościami podczas zabaw z trojgiem rówieśników niepełnosprawnych intelektualnie w stopniu umiarkowanym. Już po kilku dniach niepełnosprawne dzieci zaczęły włączać się do zabaw i podejmować rozmowy. Ta sama procedura okazała się skuteczna również $\mathrm{w}$ odniesieniu do dzieci ze znaczną niepełnosprawnością intelektualną oraz autystycznych. $\mathrm{W}$ trakcie późniejszych badań Ph. Strain i jego współpracownicy uczyli dzieci pełnosprawne, jak powinny one zachęcać niepełnosprawnych rówieśników do porozumiewania się - poprzez zadawanie pytań, proszenie o odpowiedzi, podpowiadanie partnerowi, co powinien powiedzieć. Ta procedura również przyniosła zamierzone efekty.

Podczas badań Howarda Goldsteina i Susan Wickstrom dwoje pełnosprawnych dzieci $\mathrm{w}$ wieku przedszkolnym nauczono strategii ułatwiających ich niepełnosprawnym intelektualnie rówieśnikom zainicjowanie interakcji i podtrzymanie jej przez pewien czas ${ }^{13}$. Ułatwiające strategie polegały na: 1) nawiązywaniu kontaktu wzrokowego; 2) inicjowaniu wspólnej zabawy; 3) zachęcaniu partnera do wyrażania próśb; 4) mówieniu o czynnościach wykonywanych przez partnera lub przez siebie; 5) reagowaniu na wypowiedzi partnera poprzez ich powtarzanie, rozszerzenie lub proszenie o dodatkowe informacje. Po zakończeniu szkolenia pełnosprawne dzieci posługiwały się nabytymi strategiami $\mathrm{w}$ relacjach $\mathrm{z}$ trojgiem autystycznych rówieśników podczas zajęć w przedszkolu. Już po 20 dniach liczba interakcji społecznych nawiązywanych przez dzieci $\mathrm{z}$ autyzmem znacznie wzrosła, a po zakończeniu terapii utrzymywała się na niezmienionym poziomie.

${ }^{13} \mathrm{H}$. Goldstein, S. Wickstrom, Peer intervention effect on communicative interaction among handicapped and nonhandicapped preschoolers, "Journal of Applied Behavior Analysis", 1986, nr 2, s. 209-214. 
Pam Hunt i jej współpracownicy przeprowadzili szkolenie dla pełnosprawnych uczniów w wieku dorastania ${ }^{14}$. Uczyli ich, jak należy rozmawiać $\mathrm{z}$ kolegami niepełnosprawnymi intelektualnie w stopniu głębszym. Posługiwali się przy tym podręcznikiem zawierającym ilustracje różnych sytuacji społecznych oraz zestawy słów i zwrotów używanych w takich sytuacjach. Pełnosprawni uczniowie byli instruowani, aby ich wypowiedzi nawiązywały do treści wypowiedzi partnerów i kończyły się pytaniami, ponieważ pytania bardziej obligują do udzielenia odpowiedzi niż wypowiedzi w trybie oznajmującym. Po zakończeniu szkolenia jego uczestnicy prowadzili codziennie dziesięciominutowe oddziaływania terapeutyczne. Już po kilku dniach u niepełnosprawnych uczniów nastąpił znaczny wzrost liczby prawidłowych wypowiedzi oraz wyraźny spadek liczby wypowiedzi nieadekwatnych do sytuacji.

Poprzez kolejny eksperyment $P$. Hunt i jej współpracownicy starali się ustalić, czy umiejętności nabyte przez niepełnosprawnych uczniów podlegają generalizacji, tzn. czy są używane również $\mathrm{w}$ nowych sytuacjach i kontaktach z nowymi osobami ${ }^{15}$. Dorastający uczniowie $\mathrm{z}$ niepełnosprawnością intelektualną $\mathrm{w}$ stopniu znacznym uczestniczyli w sesjach terapeutycznych prowadzonych przez pełnosprawnych rówieśników. $\mathrm{W}$ rezultacie $\mathrm{u}$ tych pierwszych nastąpił znaczny postęp $\mathrm{w}$ zakresie prowadzenia rozmów. Po zakończeniu terapii niepełnosprawni uczniowie byli obserwowani $w$ trakcie interakcji z pełnosprawnymi rówieśnikami przeszkolonymi w posługiwaniu się strategiami ułatwiającymi partnerowi prowadzenie rozmowy oraz z rówieśnikami niepoddanymi szkoleniu. Okazało się, że poziom umiejętności dialogowych niepełnosprawnych uczniów utrzymywał się na niezmienionym poziomie niezależnie od tego, czy rozmówca stosował ułatwiające strategie, czy nie.

${ }_{14}$ P. Hunt, L. Goetz, M. Alwell, W. Sailor, Using an interrupted behavior chain strategy to teach generalized communication responses to students with severe disabilities, „The Journal of The Association for Persons with Severe Handicaps”, 1988, nr 3, s. 196-204.

15 Tychże, Generalized effects of conversational skills training, "Journal of the Association for Severely Handicapped", 1990, nr 4, s. 250-260. 


\section{Skuteczność rówieśniczego tutoringu w nauczaniu dzieci z niepełnosprawnością intelektualną}

Wielu badaczy za miarę skuteczności rówieśniczego tutoringu w edukacji uczniów z niepełnosprawnością intelektualną uznaje postępy w osiągnięciach szkolnych. Joseph Fisher oraz jego współpracownicy na podstawie przeglądu literatury stwierdzili, że rówieśniczy tutoring powoduje wzrost umiejętności czytania i pisania, doskonali kompetencje matematyczne, usprawnia mowę dzieci $\mathrm{z}$ niepełnosprawnością intelektualną. Jest również korzystny dla pełnosprawnych uczniów występujących w roli tutorów, ponieważ wzbogaca ich wiedzę, kompetencje językowe, pamięć i myślenie ${ }^{16}$.

Robert Slavin badał skuteczność rówieśniczego tutoringu w edukacji matematycznej oraz językowej dzieci w wieku od 7 do 12 lat niepełnosprawnych intelektualnie $\mathrm{w}$ stopniu lekkim ${ }^{17}$. Tutorzy uczyli niepełnosprawnych rówieśników rozwiązywania zadań matematycznych oraz poprawnego czytania i pisania fragmentów tekstu. Zadania i teksty były dobierane przez nauczyciela. Tutorzy sprawdzali poprawność wykonania zadań przez niepełnosprawnych kolegów. Jeśli niepełnosprawne dziecko nie opanowało materiału $\mathrm{w} 80 \%$, dalsze nauczanie prowadził nauczyciel. Takie przypadki występowały jednak rzadko, ponieważ pełnosprawne dzieci bardzo dobrze radziły sobie w roli tutorów.

Udokumentowano, że rówieśniczy tutoring może być z powodzeniem wykorzystywany $\mathrm{w}$ nauczaniu dzieci $\mathrm{z}$ umiarkowaną i znaczną niepełnosprawnością intelektualną. Na przykład Lisa Cushing oraz Craig Kennedy uczyli pełnosprawne dzieci, jak należy postępować $\mathrm{w}$ relacjach $\mathrm{z}$ rówieśnikami niepełnosprawnymi intelektualnie $\mathrm{w}$ stopniu głębszym ${ }^{18:}$ nawiązywać interakcje, przeka-

${ }^{16}$ J.B. Fisher, J.B. Shumaker, D.D. Deshler, Searching for validated inclusive practices: A review of literature, „Focus on Exceptional Children”, 1995, nr 4, s. 1-20.

${ }_{17}$ R.E. Slavin, Cooperative learning. Theory, research and practice, Allyn \& Bacon, Boston 1995.

${ }^{18}$ L.S. Cushing, C.H. Kennedy, Academic effect of providing peer support in general education classrooms on students without disabilities, "Journal of Applied Behavior Analysis", 1997, nr 1, s. 139-151. 
zywać informacje zwrotne, zadawać pytania, prowadzić rozmowy. Przeszkolone dzieci chętnie podejmowały relacje $\mathrm{z}$ niepełnosprawnymi kolegami, co skutkowało wzrostem zaangażowania tych ostatnich w proces nauki. Szczególnie korzystne były sytuacje, w których jednym niepełnosprawnym dzieckiem zajmowało się równocześnie dwóch tutorów. Stwierdzono, że dzięki nauczającym relacjom ze sprawnymi rówieśnikami dzieci z głębszą niepełnosprawnością intelektualną dłużej koncentrowały się na wykonywanym zadaniu, chętniej podejmowały nowe wyzwania, częściej doprowadzały zadanie do końca i popełniały mniej błędów ${ }^{19}$.

Traktowanie osiągnięć szkolnych jako miary skuteczności rówieśniczego tutoringu może budzić zastrzeżenia, tym bardziej że zazwyczaj osiągnięcia szkolne są utożsamiane z wynikami, jakie dziecko uzyskało w testach wiadomości. Dlatego niektórzy badacze proponują, aby oceniać skuteczność rówieśniczego tutoringu na podstawie porównania poziomu akceptacji niepełnosprawnego dziecka przez pełnosprawnych rówieśników przed rozpoczęciem oddziaływań i po ich zakończeniu.

Joanne Putnam i jej współpracownicy sprawdzali, jak zmieniły się relacje między dziećmi sprawnymi i niepełnosprawnymi intelektualnie po ośmiu miesiącach rówieśniczego tutoringu ${ }^{20}$. Okazało się, że $\mathrm{w}$ tych klasach, w których go nie stosowano, $\mathrm{u}$ pełnosprawnych dzieci wytworzył się negatywny obraz niepełnosprawnych rówieśników. Utrzymywał się on do końca badań. W klasach, w których stosowano rówieśniczy tutoring, dzieci pełnosprawne były natomiast dobrze nastawione do niepełnosprawnych kolegów i pozytywnie ich oceniały.

Dianne Gut podkreśla, że rówieśniczy tutoring pomaga przezwyciężyć izolację społeczną dzieci z niepełnosprawnością intelek-

19 A.F. Ashman, Peer mediation and students with diverse learning needs, [w:] Co-operative learning. The social and intellectual outcomes of learning in groups, red. R.M. Gillies, A.F. Ashman, Taylor \& Francis, New York 2005, s. 92-93.

${ }^{20}$ J. Putnam, K. Markovchick, D.W. Johnson, R.T. Johnson, Cooperative learning and peer acceptance of students with learning disabilities, "Journal of Social Psychology", 1996, nr 6, s. 741-752. 
tualną, pozwala wejść $\mathrm{w}$ pozytywne relacje $\mathrm{z}$ pełnosprawnym rówieśnikiem i nawiązać z nim koleżeńskie więzi ${ }^{21}$. Autorka analizowała, jakie zmiany w zachowaniach niepełnosprawnych dzieci, wcześniej izolowanych przez rówieśników, zaszły po objęciu ich rówieśniczym tutoringiem. Okazało się, że znacznie wzrósł poziom ich zaangażowania się w czynności związane z uczeniem się; dzieci uważniej słuchały, zadawały pytania, angażowały się w rozwiązywanie zadań i współpracowały z tutorem.

Jak dowodzą niektóre badania, po przeprowadzeniu nauczających oddziaływań poziom akceptacji dzieci z niepełnosprawnością intelektualną nie zwiększył się, co wskazuje na nieskuteczność rówieśniczego tutoringu. Przyczyn takiego stanu rzeczy należy się dopatrywać w trudnych, a nawet destruktywnych zachowaniach niepełnosprawnych dzieci. Wycofywanie się z kontaktów, zachowania agresywne lub bardzo niski poziom samokontroli emocjonalnej znacznie utrudniają, a niekiedy wręcz uniemożliwiają współpracę z tutorem. Na przykład Bonnie Brinton i jej współpracownicy napotkali na znaczne utrudnienia w zastosowaniu rówieśniczego tutoringu wobec dzieci z zaburzeniami mowy opóźnionych $w$ rozwoju intelektualnym ${ }^{22}$. Dzieci te niechętnie włączały się $\mathrm{w}$ relacje $\mathrm{z}$ rówieśnikami, unikały podejmowania zadań, preferowały czynności wykonywane w samotności i angażowały się w działania niezwiązane z pracą grupy. Nieskuteczne było też udzielanie im szczegółowych instrukcji na temat tego, jak powinny współpracować z tutorem. Badania B. Brinton dowodzą, że posiadanie przez niepełnosprawne dziecko odpowiedniego zasobu umiejętności interpersonalnych jest niezbędnym warunkiem jego integracji z pełnosprawnymi rówieśnikami, a zwłaszcza owocnej współpracy z tutorem. Oznacza to, że może nie być właściwe ani korzystne kwalifikowanie niektórych dzieci z niepełnosprawnością intelektu-

${ }^{21}$ D.M. Gut, We are social beings learning how to learn cooperatively, "Teaching Exceptional Children", 2000, nr 4, s. 46-53.

22 B. Brinton, M. Fujiki, L.M. Higbee, Participation in cooperative learning activities by children with specific language impairment, "Journal of Speech, Language and Hearing Research", 1998, nr 5, s. 1193-1206. 
alną do udziału w rówieśniczym tutoringu, zanim nie opanują one odpowiednich umiejętności. Aby dzieci mogły skorzystać z takiej formy pomocy, muszą zostać spełnione dwa warunki. Po pierwsze, nauczyciele oraz pełnosprawni rówieśnicy muszą dobrze znać sposób funkcjonowania niepełnosprawnych dzieci. Po drugie, niepełnosprawne dzieci muszą mieć umiejętności społeczne i interpersonalne umożliwiające udział $\mathrm{w}$ interakcjach $\mathrm{z}$ tutorem.

W niektórych badaniach podstawami oceny skuteczności rówieśniczego tutoringu były wywiady $\mathrm{z}$ nauczycielami posługującymi się tą metodą. Zostali oni poproszeni o ocenę uzyskiwanych efektów oraz korzyści wynoszonych przez niepełnosprawne dzieci i tutorów. Rollanda O'Connor i Joseph Jenkins prosili, aby nauczyciele uzasadnili, dlaczego stosują rówieśniczy tutoring, przedstawili jego cele i opinie o efektywności ${ }^{23}$. Nauczyciele stwierdzili, że skuteczność rówieśniczego tutoringu zależy przede wszystkim od sposobu doboru par tutor - uczeń, systematyczności nadzoru nad parami oraz typu nauczających strategii stosowanych przez tutorów.

Brakuje badań, które pozwoliłyby odpowiedzieć na pytanie o to, jak niepełnosprawne dzieci oceniają skuteczność rówieśniczego tutoringu. Pewne dane na ten temat zgromadzili J. Putnam i jej współpracownicy24: 74\% uczniów ze specjalnymi potrzebami edukacyjnymi deklarowało, że lubi uczyć się we współpracy ze sprawnymi rówieśnikami, 13\% nie potrafiło zająć stanowiska w tej kwestii, a 13\% stwierdziło, iż nie lubi takiej formy nauczania.

Zgromadzone dotychczas dane pozwalają stwierdzić, że rówieśniczy tutoring może być z powodzeniem wykorzystywany w edukacji uczniów z niepełnosprawnością intelektualną. Metoda ta przyczynia się do postępów w nauce i rozwoju kompetencji społecznych dziecka. Zwiększa m.in.: poziom wiedzy, motywację do nauki, zaangażowanie w wykonywane zadania oraz jakość interakcji z pełnosprawnymi rówieśnikami i nauczycielem, poprawia pozycję w grupie rówieśniczej.

${ }^{23}$ R.E. O'Connor, J.R. Jenkins, Cooperative learning as an inclusion strategy: a closer look, „Exceptionality”, 1996, nr 1, s. 29-51.

24 J. Putnam, K. Markovchick, D.W. Johnson, R.T. Johnson, op. cit., s. 741-752. 


\section{Nauczyciel jako organizator rówieśniczego tutoringu}

Włączenie pełnosprawnych rówieśników $\mathrm{w}$ proces edukacji dzieci z niepełnosprawnością intelektualną może być dla nauczyciela poważnym wyzwaniem. Warto bowiem zauważyć, że jeszcze w 2005 r. wśród prac dotyczących rówieśniczego tutoringu nie było takich, które zawierałyby propozycje empirycznie zweryfikowanych programów przygotowania nauczycieli do posługiwania się tą metodą $\mathrm{w}$ stosunku do niepełnosprawnych dzieci $\mathrm{w}$ toku zajęć szkolnych ${ }^{25}$. Dopiero w ostatnich latach pojawiły się opracowania dotyczące dzieci z niektórymi rodzajami niepełnosprawności ${ }^{26}$.

Nauczyciel jako organizator rówieśniczego tutoringu nie może dopuścić do tego, aby cały ciężar oddziaływań edukacyjnych spoczywał na barkach pełnosprawnych dzieci. Ich oddziaływania powinny być elementami procesu nauczania prowadzonego przez nauczyciela i pozostawać pod jego ścisłym nadzorem. To oznacza, że musi on zrealizować wiele zadań. Poniżej zostały przedstawione najważniejsze $\mathrm{z}$ nich ${ }^{27}$.

1. Wybór pełnosprawnych dzieci do roli tutorów. Nauczyciel musi pamiętać, że dzieci, którym powierza role tutorów, powinny być wysoko uspołecznione, tzn. dysponować bogatym repertuarem zachowań prospołecznych i mieć wysoki poziom kompetencji komunikacyjnej. Powinny też być pozytywnie nastawione do niepełnosprawnych rówieśników i chętnie nawiązywać z nimi interakcje. Ponadto powinny prawidłowo reagować na instrukcje i polecenia nauczyciela.

${ }^{25}$ E. Murphy, I.M. Grey, R. Honan, op. cit., s. 163.

26 A.N. Grauvogel-MacAleese, M.D. Wallace, Use of peer-mediated intervention in children with attention deficit hyperactivity disorder, "Journal of Applied Behavior Analysis", 2010, nr 3, s. 547-551; T. Smith, Making inclusion work for students with autism spectrum disorders, Guilford Press, New York 2012.

27 A. Twardowski, Rola petnosprawnych rówieśników w procesie wspomagania rozwoju dzieci niepetnosprawnych, [w:] Wspomaganie rozwoju i rehabilitacja dzieci $z$ genetycznie uwarunkowanymi zespołami zaburzeń, red. idem, Wydawnictwo Naukowe PTP, Poznań 2004, s. 91-92. 
2. Przygotowanie tutorów. Kandydaci do roli tutorów muszą nie tylko dysponować odpowiednio wysokim poziomem wiedzy, lecz także wiedzieć, jak przekazywać ją mniej kompetentnym kolegom. W tym celu powinni zostać poddani specjalnym szkoleniom $\mathrm{z}$ wykorzystaniem metod modelowania oraz grania ról. Przyszli tutorzy muszą nauczyć się m.in.: jak nawiązywać i podtrzymywać nauczające interakcje, jakich materiałów dydaktycznych używać, w jaki sposób przekazywać informacje, jak pytać oraz odpowiadać na pytania, jak identyfikować błędy i jak je korygować, jakie nagrody stosować.

3. Dobór par tutor - uczeń. Przy łączeniu dzieci w pary nauczyciel powinien uwzględnić ich zainteresowania oraz stopień wzajemnej akceptacji. W parze powinny znaleźć się dzieci, które lubią ze sobą przebywać i chętnie podejmują wspólne czynności. Jak zauważają David Johnson i Roger Johnson, rówieśniczy tutoring nie przynosi spodziewanych efektów, gdy dzieci są łączone $\mathrm{w}$ diady, triady oraz poliady w sposób przypadkowy i na krótki czas ${ }^{28}$. W takiej sytuacji partnerzy większość czasu poświęcają na wzajemne poznawanie się kosztem czynności związanych z nauką.

4. Stwarzanie sytuacji sprzyjających nawiązywaniu nauczających interakcji. Temu celowi służy wykorzystywanie naturalnie pojawiających się sytuacji i okoliczności, w których dzieci muszą współpracować, aby osiągnąć określone cele. Nauczyciel powinien zapewnić dzieciom zabawki i pomoce dydaktyczne sprzyjające podejmowaniu działań o charakterze kooperacyjnym. Powinien uczyć tutorów strategii ułatwiających zainicjowanie interakcji z niepełnosprawnymi rówieśnikami. Takimi strategiami są: nawiązywanie kontaktu wzrokowego, podzielanie uwagi, mówienie o czynnościach partnera, zadawanie pytań, proszenie o informacje, nakłanianie partnera, aby spełnił określoną prośbę.

${ }^{28}$ D.W. Johnson, R.T. Johnson, Learning together and alone: cooperative, competitive and individualistic learning, Allyn \& Bacon, Boston 1994. 
5. Monitorowanie zmian $\mathrm{w}$ umiejętnościach niepełnosprawnych dzieci. Nauczyciel powinien uważnie śledzić przebieg zajęć i zachęcać tutorów do stosowania nauczających strategii. Musi podpowiadać, jakich strategii mają użyć, nagradzać za ich poprawne zastosowanie oraz korygować ewentualne błędy. Wymienione czynności są niezbędne, ponieważ pozytywne zmiany $\mathrm{u}$ niepełnosprawnych intelektualnie dzieci mogą pojawić się dopiero po 30 lub 40 sesjach rówieśniczego tutorin$\mathrm{gu}^{29}$. Ponadto nauczyciel powinien od czasu do czasu przeprowadzać dodatkowe sesje szkoleniowe dla tutorów, aby przypomnieć im niektóre strategie lub nauczyć ich nowych.

6. Stopniowe wycofywanie bezpośredniego nadzoru nad nauczającymi interakcjami. W miarę nabywania przez pełnosprawne dzieci wprawy w posługiwaniu się nauczającymi strategiami nauczyciel może stopniowo ograniczać kontrolę i pozwalać im na coraz bardziej samodzielne działania. Powinien skoncentrować się na organizowaniu zajęć sprzyjających prowadzeniu rówieśniczego tutoringu oraz dyskretnie nadzorować postępowanie tutorów. Musi ustalić prosty, a jednocześnie skuteczny system wymiany informacji z tutorami. $\mathrm{Na}$ przykład każdej strategii można przypisać jeden z piktogramów zawieszonych na ścianie, widocznych z różnych miejsc i odległości. Piktogramy pełnią wówczas podwójną funkcję. Po pierwsze, przypominają tutorom o poszczególnych strategiach. Po drugie, nauczyciel poprzez wskazywanie odpowiednich symboli może podpowiadać tutorom, jaką strategią powinni się posłużyć w danej sytuacji.

Dotychczasowe badania dowodzą, że dzięki nauczającym interakcjom z pełnosprawnymi rówieśnikami dzieci z niepełnosprawnością intelektualną częściej uczestniczą w zabawach zespołowych, częściej nawiązują interakcje z kolegami, chętniej z nimi rozmawiają oraz rzadziej przejawiają zachowania społecznie nieakceptowa-

${ }^{29}$ M.J. Guralnick, Peer interactions and development of handicapped children's social and communicative competence, [w:] Children helping children, ed. cit., s. 275-305. 
ne ${ }^{30}$. Po zakończeniu oddziaływań nabyte umiejętności utrzymują się na niezmienionym poziomie i są używane w nowych sytuacjach. Zatem warto wykorzystywać metodę rówieśniczego tutoringu w edukacji dzieci z niepełnosprawnością intelektualną. Nie można jednak zapominać o tym, że skuteczność tej metody zależy od tego, jak nauczyciel poradzi sobie z przedstawionymi powyżej zadaniami.

\section{Problemy wymagające dalszych badań}

Wykorzystanie rówieśniczego tutoringu w edukacji dzieci z niepełnosprawnością intelektualną rodzi wiele pytań, wymagających weryfikacji w dalszych badaniach. Poniżej umieszczono najważniejsze $\mathrm{z}$ nich.

1. Jak włączyć rówieśniczy tutoring w klasowo-lekcyjny system organizacji pracy szkoły? Jak zaaranżować przestrzeń klasy i jakie pomoce dydaktyczne zgromadzić? Jak zorganizować zajęcia, aby pracujące pary lub zespoły nie przeszkadzały sobie nawzajem? I wreszcie - jakie dodatkowe przygotowanie powinien mieć nauczyciel, aby z powodzeniem posługiwać się tą metodą, i w jaki sposób może je zdobyć? ${ }^{31}$

2. Czy to możliwe, aby w roli nauczyciela występował uczeń, który nie jest ekspertem w dziedzinie będącej przedmiotem nauczania i wie niewiele więcej od swojego ucznia? Jak uznał Jerome Bruner, taki „nauczyciel” nie zapozna ucznia z głęboką strukturą wiedzy i nie odpowie wyczerpująco na pytania

${ }^{30}$ J.R. Jenkins, L.R. Antil, S.K. Wayne, P.F. Vadasy, How cooperative learning works for special education and remedial students, "Exceptional Children”, 2003, nr 3, s. 279-292.

31 A. Twardowski, Wptyw nauczających relacji z petnosprawnymi rówieśnikami na rozwój dzieci z niepetnosprawnościami, [w:] Pedagogika specjalna - koncepcje i rzeczywistość. Socjopedagogiczne aspekty rehabilitacji osób niepetnosprawnych, red. T. Żółkowska, M. Wlazło, ZAPOL, Szczecin 2008, s. 150. 
o znaczenie różnych pojęć oraz relacje między nimi ${ }^{32}$. Stąd możliwe, że rówieśniczy tutoring jest skuteczny na poziomie poznania, zrozumienia i zastosowania, ale nie na poziomie analizy, syntezy i oceny.

3. W jaki sposób ustalić, kto kogo ma uczyć? Czy uczniowie mają decydować o tym sami, czy też decyzje powinien podejmować nauczyciel? Jeśli przyjmie się pierwszy wariant, to co uczynić, gdy wybory nie będą wzajemne, a zwłaszcza gdy znajdą się niepełnosprawni uczniowie, których nikt nie wybierze? Czy skuteczność rówieśniczego tutoringu jest wyższa, gdy w parze są dzieci tej samej płci, czy też gdy są różnych płci? Czy w roli tutorów lepiej sprawdzają się dziewczynki, czy chłopcy? W relacjach z jakimi partnerami?

4. Jaką postawę wobec rówieśniczego tutoringu zajmują rodzice dzieci sprawnych i niepełnosprawnych? Rodzice dzieci sprawnych mogą nie popierać rówieśniczego tutoringu, szczególnie gdy nie dostrzegają w nim korzyści dla swojego dziecka. We współczesnej szkole dominuje rywalizacja, a nie współpraca, dlatego niektórzy rodzice mogą uznać, że czas, który ich dziecko poświęca gorzej uczącemu się koledze, jest czasem straconym dla jego własnej nauki.

5. Jak przezwyciężyć problemy natury etycznej? Przede wszystkim nauczyciel musi zadbać o to, aby rówieśniczy tutoring był korzystny zarówno dla tutora, jak i ucznia. W przypadku gdy uczniami są dzieci niepełnosprawne intelektualnie, pojawia się problem, co sprawni tutorzy powinni wiedzieć o niesprawności swoich partnerów i wpływie tej niesprawności na przebieg nauki. Czy uczniowie pełniący funkcje tutorów powinni uczestniczyć w spotkaniach nauczycieli, na których omawia się ich prace i analizuje postępy „uczniów”? Jak chronić uczniów występujących w roli tutorów przed nieuzasadnionym przekonaniem o własnej wyjątkowości i posiadaniu szczególnych umiejętności?

32 J.S. Bruner, W poszukiwaniu teorii nauczania, Państwowy Instytut Wydawniczy, Warszawa 1974. 
6. Jak budować pozytywne nastawienie do rówieśniczego tutoringu u decydentów oświatowych, nauczycieli i rodziców? Przede wszystkim trzeba zmienić tradycyjny pogląd, zgodnie z którym prawdziwą wiedzę dziecko może uzyskać tylko od nauczyciela, a ta zdobyta od rówieśników nie ma wartości z perspektywy celów kształcenia. Należy również wyeliminować dość powszechne przekonanie o tym, że nauczyciel, który przekazuje swoje uprawnienia uczniom, lekceważy własne obowiązki i nie rozumie, jak trudna i odpowiedzialna jest jego praca. Decydenci, rodzice oraz nauczyciele muszą zrozumieć, że bywają sytuacje, w których niepełnosprawne dziecko „z niewielką pomocą swoich przyjaciół" może osiągnąć równie wiele, a nawet więcej niż wtedy, kiedy edukują je wyłącznie nauczyciele.

Dotychczasowe doświadczenia związane z rówieśniczym tutoringiem wskazują na to, że przyczynia się on do wzrostu osiągnięć wszystkich uczniów, a także tworzy bardziej przyjazną, życzliwą atmosferę w klasie. Uczniowie mają możliwość dzielenia się pomysłami i wymiany posiadanych wiadomości. Tym samym zwiększa się liczba źródel, z których czerpią wiedzę. Rówieśniczy tutoring stymuluje kreatywność uczniów, zwiększa zainteresowanie wykonywanymi zadaniami i podwyższa motywację do nauki ${ }^{33}$.

\section{Zakończenie}

Włączenie pełnosprawnych rówieśników w proces edukacji dzieci niepełnosprawnych jest korzystne dla jednych i drugich. Pełnosprawne dzieci mogą lepiej zrozumieć przekazywane treści, bowiem uczenie kogoś sprzyja uporządkowaniu i pogłębieniu własnej wiedzy na określony temat. W obszarze rozwoju społeczno-moralnego tutoring może zwiększyć wrażliwość na potrzeby niepełnosprawnych kolegów, poczucie odpowiedzialności oraz empatię. W sferze kształtowania się osobowości może przyczynić się do wzro-

${ }^{33}$ K.M. Tateyama-Sniezek, Cooperative learning: does it improve the academic achievement of students with handicaps?, „Exceptional Children”, 1990, nr 5, s. 426-437. 
stu samooceny, wiary we własne możliwości oraz poczucia własnej wartości. Dzięki rówieśniczemu tutoringowi dzieci pełnosprawne mogą lepiej poznać i zrozumieć swoich niepełnosprawnych kolegów. Mają okazję przekonać się, że z niepełnosprawnymi rówieśnikami można się bawić oraz rozmawiać, można się od nich wiele nauczyć, a ich świat wewnętrzny jest bogaty i godny poznania.

Nauczanie przez pełnosprawnych rówieśników przynosi również liczne korzyści dzieciom niepełnosprawnym intelektualnie. Przede wszystkim wzbogaca ich wiedzę i umiejętności. Dzięki rówieśniczemu tutoringowi zwiększa się poziom zaangażowania niepełnosprawnych dzieci w życie grupy, intensyfikują się ich kontakty z kolegami oraz wzrasta liczba rozmów, w których mogą one z powodzeniem uczestniczyć. Niepełnosprawne dzieci mogą przekonać się, że sprawni rówieśnicy obdarzają je uwagą, chcą się z nimi uczyć i spędzać czas; mają okazję zrozumieć, że dzięki nabytym umiejętnościom mogą skutecznie wpływać na innych ludzi i osiągać zamierzone cele. $W$ ten sposób u dzieci niepełnosprawnych intelektualnie kształtuje się poczucie kompetencji, czyli przeświadczenie, że potrafią sprawować kontrolę nad sobą i otoczeniem. Zwiększa się również ich autonomia, ponieważ w relacjach z rówieśnikami muszą bardziej polegać na sobie i wspólnie z partnerami wypracowywać programy działania.

Należy mocno podkreślić to, że rówieśniczy tutoring ma szczególne znaczenie dla nauczania integracyjnego. Zwrócenie uwagi na możliwość występowania przez pełnosprawnych uczniów w rolach nauczycieli niepełnosprawnych kolegów pozwala postrzegać klasę jako miejsce, w którym jednocześnie znajduje się tylu nauczycieli, ilu jest uczniów, a nie takie, w którym wszystkich uczniów uczy jeden nauczyciel.

\section{Bibliografia}

ASHMAN A.F., Peer mediation and students with diverse learning needs, [w:] Co-operative learning. The social and intellectual outcomes of learning in groups, red. R.M. Gillies, A.F. Ashman, Taylor \& Francis, New York 2005. 
BRINTON B., FUJIKI M., HIGBEE L.M., Participation in cooperative learning activities by children with specific language impairment, "Journal of Speech, Language and Hearing Research", 1998, nr 5.

BRUNER J.S., W poszukiwaniu teorii nauczania, Państwowy Instytut Wydawniczy, Warszawa 1974.

CARTER E.W., Cushing L.S., KenNedy C.H., Peer support strategies: improving all student's social lives and learning, Paul H. Brookes, Baltimore 2009.

Children helping children, red. H.C. Foot, M.J. Morgan, R.H. Shute, John Willey \& Sons, New York 1990.

COOPER C.R., Development of collaborative problem-solving among preschool children, "Developmental Psychology", 1980, nr 5.

CUSHING L.S., KENNEDY C.H., Academic effect of providing peer support in general education classrooms on students without disabilities, "Journal of Applied Behavior Analysis", 1997, nr 1.

DAMOND W., PHELPS E., Strategies uses of peer learning in children's education, [w:] Peer relationships in child development, red. T.J. Berndt, G.W. Ladd, John Willey \& Sons, New York 1989.

DOISE W., The development of individual competencies through social interaction, [w:] Children helping children, red. H.C. Foot, J.M. Morgan, R.H. Shute, John Wiley \& Sons, New York 1990.

FISHER J.B., SHUMAKER J.B., DESHLER D.D., Searching for validated inclusive practices: A review of literature, „Focus on Exceptional Children”, 1995, nr 4.

FonTANA D., Where do we go from here? A personal view by an educationalist, [w:] Children helping children, red. H.C. Foot, M.J. Morgan, R.H. Shute, John Willey \& Sons, New York 1990.

GOLDSTEIN H., WICKSTROM S., Peer intervention effect on communicative interaction among handicapped and nonhandicapped preschoolers, "Journal of Applied Behavior Analysis", 1986, nr 2.

GRAUVOGEL-MACAlEESE A.N., WALLACE M.D., Use of peer-mediated intervention in children with attention deficit hyperactivity disorder, "Journal of Applied Behavior Analysis", 2010, nr 3.

GURALNICK M.J., Peer interactions and development of handicapped children's social and communicative competence, [w:] Children helping children, red. H.C. Foot, M.J. Morgan, R.H. Shute, John Wiley \& Sons, New York 1990.

GUT D.M., We are social beings learning how to learn cooperatively, „Teaching Exceptional Children", 2000, nr 4.

HunT P., AlWELL M., GOETZ L., SAILOR W., Generalized effects of conversational skills training, "Journal of the Association for Severely Handicapped”, 1990, nr 4.

HunT P., GOETZ L., ALWELL M., SAILOR W., Using an interrupted behavior chain strategy to teach generalized communication responses to students with severe disabilities, "The Journal of The Association for Persons with Severe Handicaps", 1988, nr 3. 
JENKINS J.R., ANTIL L.R., WAYNE S.K., VADASY P.F., How cooperative learning works for special education and remedial students, „Exceptional Children”, 2003, nr 3.

JOHNSON D.W., JOHNSON R.T., Learning together and alone: cooperative, competitive and individualistic learning, Allyn \& Bacon, Boston 1994.

MURPHY E., GREY I.M., HONAN R., Co-operative learning for students with difficulties in learning: a description of model and guidelines for implementation, „British Journal of Special Education", 2005, nr 3.

O'CONNOR R.E., JENKINS J.R., Cooperative learning as an inclusion strategy: a closer look, „Exceptionality”, 1996, nr 1.

PutNAm J., MARKOVCHICK K., JOHNSON D.W., JOHNSON R.T., Cooperative learning and peer acceptance of students with learning disabilities, "Journal of Social Psycho$\log \mathrm{y}^{\prime \prime}, 1996, \mathrm{nr} 6$.

SLAVIN R.E., Cooperative learning. Theory, research and practice, Allyn \& Bacon, Boston 1995.

SMITH T., Making inclusion work for students with autism spectrum disorders, Guilford Press, New York 2012.

STRAIN Ph.S., SHORES R.E, TIMM M.A., Effects of peer social initiations on the behavior of withdrawn preschool children, "Journal of Applied Behavior Analysis", 1977, nr 2.

TATEYAMA-SNIEZEK K.M., Cooperative learning: does it improve the academic achievement of students with handicaps?, „Exceptional Children”, 1990, nr 5.

Tudge J., Rogoff B., Wptyw rówieśników na rozwój poznawczy - podejście Piageta i Wygotskiego, [w:] Dziecko wśród rówieśników i dorostych, red. A. Brzezińska, G. Lutomski, B. Smykowski, Wydawnictwo Zysk i S-ka, Poznań 1995.

TWARDOWSKI A., Rola petnosprawnych rówieśników w procesie wspomagania rozwoju dzieci niepetnosprawnych, [w:] Wspomaganie rozwoju i rehabilitacja dzieci z genetycznie uwarunkowanymi zespotami zaburzeń, red. idem, Wydawnictwo Naukowe PTP, Poznań 2004.

TWARDOWSKI A., Wptyw nauczajacych relacji z petnosprawnymi rówieśnikami na rozwój dzieci z niepetnosprawnościami, [w:] Pedagogika specjalna - koncepcje i rzeczywistość. Socjopedagogiczne aspekty rehabilitacji osób niepetnosprawnych, red. T. Żółkowska, M. Wlazło, ZAPOL, Szczecin 2008.

WYGOTSKI L.S., Wybrane prace psychologiczne, PWN, Warszawa 1971. 